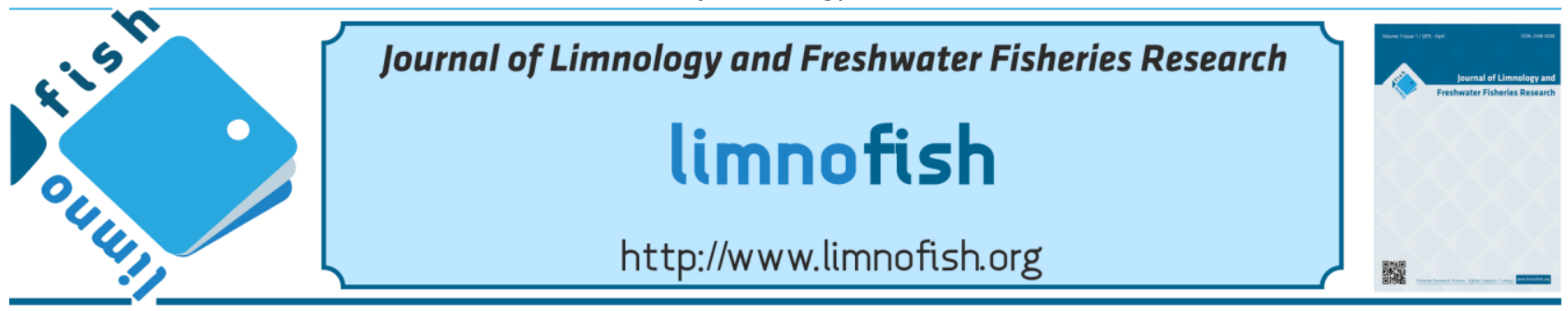

Water Quality in Tortum Stream and its Tributaries (Erzurum/Turkey)

\author{
Mine KÖKTÜRK*, Muhammed ATAMANALP \\ Atatürk University, Fisheries Faculty, 25240 Erzurum-Turkey
}

\section{A B STRACT}

This study was undertaken with the aim of determining the effects of domestic waste and hydroelectric dams on water quality in the Tortum Stream and its tributaries. Water samples were taken monthly from nine sampling points of Tortum Stream and its tributaries between July 2012 and May 2013. Analyzed for temperature $\left({ }^{\circ} \mathrm{C}\right), \mathrm{pH}$, dissolved oxygen (DO), total suspended solids (TSS), alkalinity, $\mathrm{Ca}$, total hardness, sulfate $\left(\mathrm{SO}_{4}\right)$, ammonia-nitrogen $\left(\mathrm{N}^{-\mathrm{NH}_{3}}{ }^{-}\right)$, nitrite-nitrogen $\left(\mathrm{N}^{-\mathrm{NO}_{2}}{ }^{-}\right)$and nitrate nitrogen $\left(\mathrm{N}^{-\mathrm{NO}_{3}}{ }^{-}\right)$as well as total phosphorus (TP), total orthophosphate (TO), total iron and silica $\left(\mathrm{SiO}_{2}\right)$ were carried out. Physical and chemical characteristics of Tortum Stream and its tributaries which were examined according to the Water Framework Directive and the Water Pollution Control Regulations. It can be said that the stream has a low water quality standard except for water temperature, dissolved oxygen and sulfate. The results showed that Tortum Stream and tributaries are under threat because of domestic waste, fertilizers and hydroelectric constructions.

Keywords: Ammonia-Nitrogen, Total Phosphorus, Total Iron, Silica, Tortum Stream

\section{ARTICLE INFO}

\section{RESEARCH ARTICLE}

Received : 26.01.2015

Revised : 20.03.2015

Accepted :21.03.2015

Published : 20.04.2015

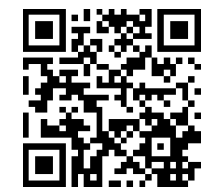

\section{* CORRESPONDING AUTHOR}

minekokturk@hotmail.com

Tel : +90 4422312566

Fax: +904422361128

\title{
Tortum Çayı ve Kollarının (Erzurum/Türkiye) Su Kalitesi
}

Öz: Bu çalışma, Tortum Çayı ve Kollarına evsel atıkların ve hidroelektrik santral inşaatının su kalitesine etkisini belirlemek amacıyla yapılmıştır. Tortum Çayı ve Kollarında belirlenen 9 istasyonda Haziran 2012- Mayıs 2013 tarihleri arasında aylık su örnekleri alınmıştır. Bu örneklerde toplam fosfor, ortafosfat, toplam demir ve silikat değerlerine ek olarak sıcaklık, $\mathrm{pH}$, çözünmüş oksijen, Ca-sertliği, toplam sertlik, alkalinite, askıda katı madde, sülfat, amonyak-azotu, nitrit-azotu, nitrat-azotu değerleri analiz edilmiştir. Tortum Çayı ve kollarının fiziksel ve kimyasal özellikleri, Su Çerçeve Direktifi ve Su Kirliliği Yönetmeliği Kıta İçi Su Kalite Standartlarına göre incelendiğinde su sıcaklığı, çözünmüş oksijen ve sülfat değerleri hariç düşük kaliteli su standartlarında olduğu söylenebilir. Sonuç olarak Tortum Çayı ve Kollarından gelen evsel atık, hayvansal orjinli gübre ve hidroelektrik santrallerinin inşaat atıkları sebebiyle kirlilik tehdidi altındadır.

Anahtar kelimeler: Amonyak-azotu, Toplam Fosfor, Toplam Demir, Silikat, Tortum Çayı

\section{Introduction}

A river is a system comprising both the main course and the tributaries, carrying the one-way flow of a significant load of matter in dissolved and particulate phases from both natural and anthropogenic sources. The quality of a river at any point reflects several major influences, including the lithology of the basin, atmospheric inputs, climatic conditions and anthropogenic inputs (Bricker and Jones 1995). On the other hand, river water quality is influenced not only by natural processes including soil erosion, precipitation and seasonal variation but also by anthropogenic activities, such as the construction of reservoirs, urban developments, and runoff from industrial/hazard waste sites and adjacent sewage treatment plants (Kelley and Hudson 2007; Su and Yang 2008; Gutierrez et al. 2008).

Rivers play a major role in assimilation or carrying off municipal and industrial wastewater and runoff from agricultural land. The municipal and industrial wastewater discharge constitutes a constant polluting source, whereas, the surface run-off is a seasonal phenomenon. Seasonal variations in rainfall, surface run-off, interflow, ground water flow and pumped in and outflows have strong effects on river discharge and subsequently on the concentration of pollutants in river water (Vega et al. 1998).

In hydropower plants, the water that goes to the turbines is taken from the lower layers of the reservoirs, sometimes with low DO content, 
which can affect the downstream water quality. The DO level from downstream water depends also on water head, periodic temperature variations, intensity and frequency of rain, hydropower plant design and its operation regimes. The number of studies concerning water quality from hydropower releases increased. Many environment or ecological issues were reported, in different types of hydroelectric schemes. Scientist and engineers try to find solutions and mechanisms which will improve water quality, especially DO level. Generally, the low DO level is caused by organic sediments left on the reservoir bottom floor from the initial filling. When these organic sediments decompose, they absorb the oxygen from water, producing hydrogen sulphide, carbon dioxide and methane (like greenhouse gas). This pollution alters the local flora and fauna, even causing total extermination of some aquatic species (Bunea et al. 2012).

Epipelic diatoms and some physico-chemical features of Tortum streams were studied in the samples collected monthly from four sampling-stations during June 2005-February 2006. A total of 113 taxa of epipelic diatom were determined. The composition of dominant taxa and results of chemical analysis indicated that Tortum streams was polluted organically (Kıvrak and Gürbüz 2010).

In order to determine the water quality of rivers and lakes systems several criteria have been developed. Some of these criteria are considered by the world in general, some of the criteria that have been developed specifically for each country. The validity of the whole world that the WHO 2004 (World Health Organization), prepared by the European countries, as well as water quality values in Turkey, prepared by the Water Framework Directive and the Water Pollution Control Regulations in the law by the Inland Surface Waters Standards of inland waters was divided into four main classes (Anonymous 2012).

The Tortum Stream is the most important resource landslides which feeds the lake and the third largest waterfall of the world. There are four trout farm, four stone quarries, two concrete plants as well as use of irrigation water and three Hydroelectric Dams Project are not completed on the Tortum Stream and its tributaries.

This study was carried out in order to see what information could be gained from this data, and to monitor the seasonal changes of these parameters and the present water quality of the Tortum Stream and its tributaries.

\section{Materials and Methods}

\section{Study area}

This study was carried out in Tortum Stream and its tributaries. Tortum Stream is located in the east part of the Anatolian region of Turkey, and the basin lies within the boundaries of Erzurum province. Tortum Stream which is one of the tributary on the Çoruh River is catchment basin and fall into Tortum Lake, after than it is to be waterfall. It has a length of about $50 \mathrm{~km}$. A fast-flowing river system is Tortum Stream basin limiting west to the mountains of the Mescit (3239 m.) and the east of Akdag Mountains $(3047 \mathrm{~m})$. Tortum stream basin consists of two units of different geomorphologic features in general. These areas are hilly with deep and narrow valley bottoms. Tortum stream basin is to be geological structure and shaped by river erosion. Significant elevation of the highest parts of the mountains and the valley floors are differenced. (Atalay et al. 1985). The map of Tortum Stream, its tributaries and the stations are given in Figure 1. Magellan brand GPS coordinates were used to determine the terrain (6 Utmed50 ${ }^{\circ} \mathrm{C}$ ).

\section{Sampling strategy}

Water samples were collected at monthly intervals between July 2012 and May 2013 in polyethylene bottles and transported to the laboratory and processed within $6 \mathrm{~h}$ of collection. Samples could not be obtained due to the terrain and road conditions in the August. Water samples had been taken from the stream center, $0.5 \mathrm{~cm}$ depth of the Tortum Stream and its tributaries. In this study, the water temperature, $\mathrm{pH}$ and dissolved oxygen values of water samples were measured in situ (Table 1) at each sampling station using a recalibrated portable $\mathrm{pH}$ meter and Oxygen meter (Terhmo brand equipment).

\section{Laboratory analysis}

The analysis were made in the laboratory of the Faculty of Fisheries at the Ataturk University in Erzurum. The Nessler's reagent method was applied to the water samples to determine the concentration of ammonia nitrogen $\left(\mathrm{NH}_{3}-\mathrm{N}\right)$, calculated colorimetrically using the Nessler reactive reagent at a wavelength of $410 \mathrm{~nm}$, The nitrite nitrogen $\left(\mathrm{NO}_{2}-\mathrm{N}\right)$ was determined by diazotizing with sulfanilamide and coupling with $\mathrm{N}$-1-naphthylenediamine dihydrochloride to form a color azo dye; colorimetric measurement was then performed by spectrophotometer at $520 \mathrm{~nm}$. In the nitrate nitrogen $\left(\mathrm{NO}_{3}-\mathrm{N}\right)$ analysis, after the reaction between nitrate ion and brucine, the absorbance of the yellow color was determined spectrophotometrically at $420 \mathrm{~nm}$ (APHA 1995). 
Table 1. Names of the location for sampling with coordinates.

\begin{tabular}{|c|c|c|c|c|}
\hline Sampling site & Name of sampling site & North latitude & East longitude & $\begin{array}{l}\text { Elevation from } \\
\text { sea level }(\mathrm{m})\end{array}$ \\
\hline 1 & Tortum Town & $40^{\circ} 17^{\prime} 21^{\prime \prime} \mathrm{N}$ & $41^{\circ} 33^{\prime} 02^{\prime \prime} \mathrm{E}$ & 1600 \\
\hline 2 & Demirciler Village & $40^{\circ} 21^{\prime} 14^{\prime \prime} \mathrm{N}$ & $41^{\circ} 30^{\prime} 35^{\prime \prime} \mathrm{E}$ & 1412 \\
\hline 3 & Vişneli Village & $40^{\circ} 24^{\prime} 23^{\prime \prime} \mathrm{N}$ & $41^{\circ} 28^{\prime} 52^{\prime \prime} \mathrm{E}$ & 1275 \\
\hline 4 & Şenyurt Village & $40^{\circ} 26^{\prime} 02^{\prime \prime} \mathrm{N}$ & $41^{\circ} 29^{\prime} 30^{\prime \prime} \mathrm{E}$ & 1239 \\
\hline 5 & Pehlivanlı Village & $40^{\circ} 29^{\prime} 47^{\prime \prime} \mathrm{N}$ & $41^{\circ} 29^{\prime} 31^{\prime \prime} \mathrm{E}$ & 1164 \\
\hline 6 & Altıçanak Village & $40^{\circ} 34^{\prime} 49^{\prime \prime} \mathrm{N}$ & $41^{\circ} 36^{\prime} 30^{\prime \prime} \mathrm{E}$ & 1039 \\
\hline 7 & Vişneli Creek & $40^{\circ} 24^{\prime} 34^{\prime \prime} \mathrm{N}$ & $41^{\circ} 29^{\prime} 20^{\prime \prime} \mathrm{E}$ & 1275 \\
\hline 8 & Şenyurt Creek & $40^{\circ} 26^{\prime} 07^{\prime \prime} \mathrm{N}$ & $41^{\circ} 29^{\prime} 35^{\prime \prime} \mathrm{E}$ & 1247 \\
\hline 9 & Ödük Creek & $40^{\circ} 29^{\prime} 34^{\prime \prime} \mathrm{N}$ & $41^{\circ} 30^{\prime} 51^{\prime \prime} \mathrm{E}$ & 1157 \\
\hline
\end{tabular}

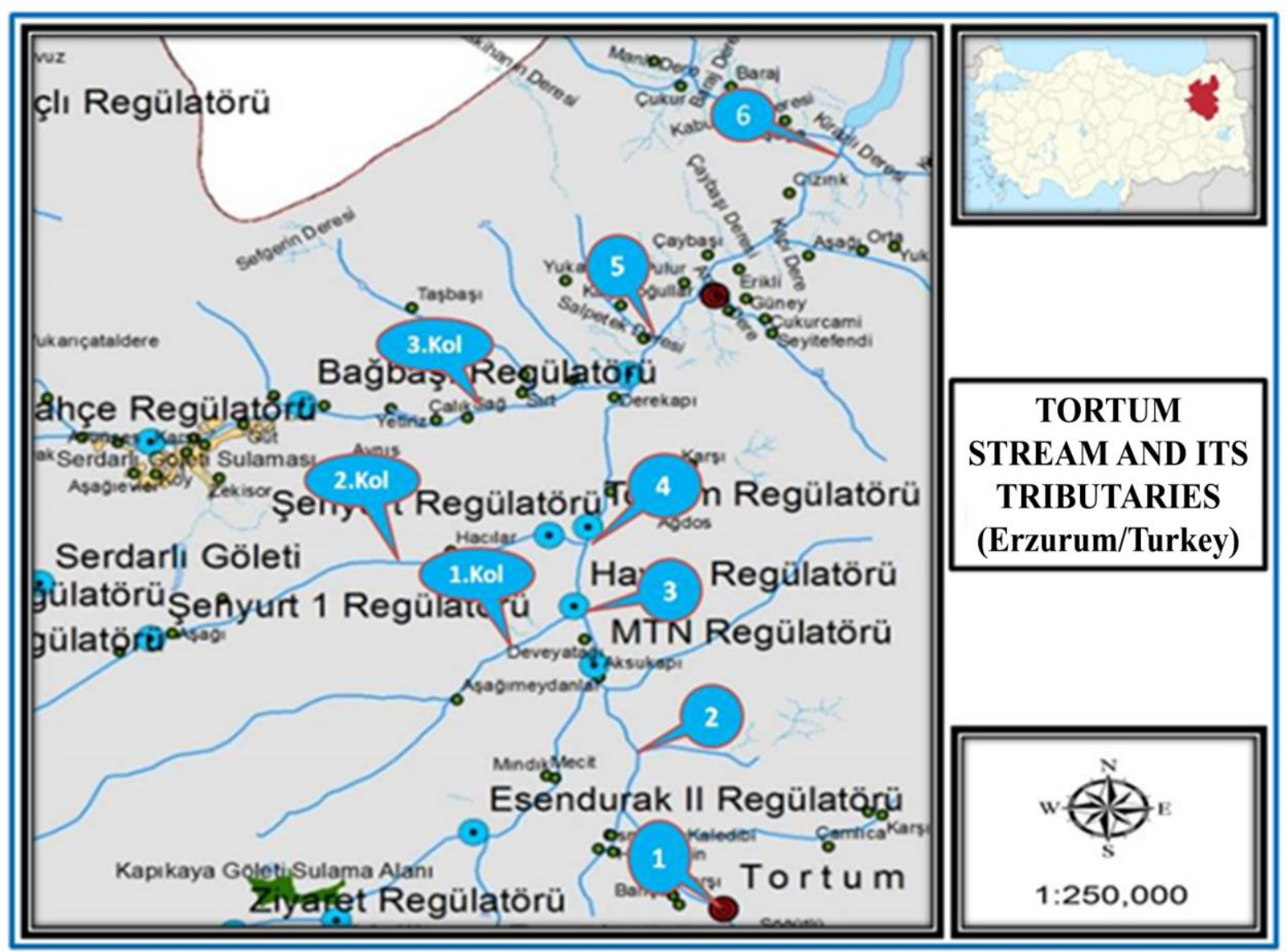

Figure 1. Map of the sampling site locations.

Water samples were analyzed for phosphorus fractions; total phosphorus (TP) and total orthophosphate $\mathrm{PO}_{4}-\mathrm{P}$ (TO) as molybdate-reactive phosphorus. Total phosphorus concentrations were analyzed by digestion using the persulphate fragmentation technique, and then both TP and TO analyses were performed, using the ascorbic acid method according to the American Public Health Association (1995). Total silica $\left(\mathrm{SiO}_{2}\right)$ analyses of water samples were done spectrophotometrically using the silicomolybdate method (Wetzel and Likens 2001). Water sample was analyzed for total iron, as phenanthroline method by spectrophotometric. Total hardness and alkalinity were measured by titrimetric method and total suspended solid matter was analyzed according to the American Public Health Association (APHA 1995).

\section{Statistical analysis}

All the statistical and mathematical analysis were made using Statistica 10 Trial and Excel 2007 programs. For the statistical analysis different tests were chosen. The data were first checked for normal distribution. ANOVA and least significant difference test (LSD) were used to evaluate differences in water samples between month and station (Kesici and Kocabaş 2007). 


\section{Results}

Water quality monitoring of Tortum Stream and its tributaries were regularly conducted during one year (2012-2013) at nine different sites. According to the findings of our study; concentration of $\mathrm{N}^{-\mathrm{NH}_{3}}{ }^{-}$, $\mathrm{N}-\mathrm{NO}_{2}{ }^{-}$and $\mathrm{N}_{-} \mathrm{NO}_{3}{ }^{-}, \mathrm{TP}, \mathrm{TO}, \mathrm{SO}_{4}, \mathrm{Fe}$ and $\mathrm{Si}$ were evaluated depend on stations and months with ANOVA, which showed that all the measured parameters were found significantly $(\% 0.05)$ and result of LSD test was showed in Table 2. As well as mean values and standard deviations of temperature $\left({ }^{\circ} \mathrm{C}\right), \mathrm{pH}$, dissolved oxygen (DO), total suspended solids (TSS), alkalinity and total hardness are summarized as $11.85 \pm 5.93{ }^{\circ} \mathrm{C}, \quad 8.72 \pm 0.34$, $12.25 \pm 3.04 \quad \mathrm{mgL}^{-1}, \quad 3.85 \pm 2.01 \quad \mathrm{mgL}^{-1}$, $72.5 \pm 47.93 \quad \mathrm{mgL}^{-1}, \quad 30.09 \pm 10.26 \mathrm{mgL}^{-1}$, $149.02 \pm 67.44 \mathrm{mgL}^{-1}$ respectively.

Water temperature ranged from 2.30 to $22.60{ }^{\circ} \mathrm{C}$. The low water temperature was may be due to the high altitude of study area. During the study period, flow rate was increasing for different aims taken sand of stream bed (for different aims e.g. construction) and we estimated that in this status effect value of the dissolved oxygen. Dissolved oxygen value ranged between 6.04 and $17.06 \mathrm{mgL}^{-1}$.

\section{Discussion}

Water temperature value of Tortum Stream and its tributaries was showed as first class quality because temperature parameter was lower than $25^{\circ} \mathrm{C}$ and dissolved oxygen according to the Water Framework Directive and the Water Pollution Control Regulations in the law by the Inland Surface Waters Standards was illustrated as first class quality because DO parameter is higher than $8 \mathrm{mgL}^{-1}$. Although not definitive, $\mathrm{pH}$ of the aquatic systems is an important indicator of the water quality and the extent pollution in the watershed areas. (Jonnalagadda and Mhere 2001). Domestic waste rate that has high value in the sample area so mean $\mathrm{pH}$ value was measured as 8.73 which is $3^{\text {rd }}$ class quality in regard to the Water Framework Directive and the Water Pollution Control Regulations in the law by the Inland Surface Waters Standards (Anonymous 2012). In addition alkalinity is in between 20 and $360 \mathrm{mgL}^{-1} \mathrm{CaCO}_{3}$.

Walling and Webb (1986) reported that the source of suspended solids matter (TSS) in water streams is both the rock and the earth minerals. Station S9 (T3) were found as $9.97 \mathrm{mgL}^{-1}$ and S6 as $9.80 \mathrm{mgL}^{-1}$ (Table 2).

Peavy et al. (1985), based on total hardness of $50 \mathrm{mgL}^{-1} \mathrm{CaCO}_{3}$, which is smaller than soft water,
50 to $150 \mathrm{mgL}^{-1} \mathrm{CaCO}_{3}$, which is of medium hard water, 150 to $300 \mathrm{mgL}^{-1} \mathrm{CaCO}_{3}$ and $300 \mathrm{mgL}^{-1}$ $\mathrm{CaCO}_{3}$ with hard water. If the total hardness is greater than the class, it will be very hard water, yet in this research; total hardness values (mean $149.02 \mathrm{mgL}^{-1}$ ) were found as medium hard water.

Three main forms of nitrogen occurrence in water were evaluated ammonia nitrogen, nitrite nitrogen and nitrate nitrogen (Brehm and Meijering 1991). Average nitrate concentration of unpolluted rivers is $100 \mu \mathrm{gL}^{-1}$. The concentrations of ammonia and nitrite are $15 \mu \mathrm{gL}^{-1}$ and $1 \mu \mathrm{gL}^{-1}$, respectively (Calow and Petts 1994). During this study, the lowest ammonia and nitrate nitrogen values were found as $0.03 \pm 0.00 \mathrm{mgL}^{-1}$ at $\mathrm{S} 3$ and $0,01 \pm 0.00 \mathrm{mgL}^{-1}$ at $\mathrm{S} 7$ (T1), the highest values were found as $0.88 \pm 0.01 \mathrm{mgL}^{-1}$ at $\mathrm{S} 2$ in September and as $0.40 \pm 0.00 \mathrm{mgL}^{-1}$ at $\mathrm{S} 2$ in October, respectively (Table 2). Nitrite value was reported unpolluted rivers as $1 \mathrm{mgL}^{-1}$ (Newbold 1992). The minimum concentration of nitrite nitrogen was $0.03 \pm 0.00 \mathrm{mgL}^{-1}$ at S5, S6, S7 (T1) and S9 (T3) in September, whereas the maximum value was detected $1.47 \pm 0.04 \mathrm{mgL}^{-1}$ at S2 in July (Table 2). In this study high nitrite nitrogen value was found owing to the sewage and domestic waste come from the villages of Tortum's tributaries.

Phosphate is an important parameter to assess the water quality. Photosynthesis and respiration play an important role in the self- purification of natural water. The disturbance of the stationary state between photosynthesis and respiration leads to chemical and biological changes reflecting pollution. High levels of these species increase the growth of vegetation in water systems and increase the oxygen demand (Jonnalagadda and Mhere 2001). Lowest levels of total orthophosphate and total phosphate in the Tortum waters were observed $0.00 \pm 0.00 \mathrm{mgL}^{-1}$ at $\mathrm{S} 6$, S7 and S9 in December and $0.00 \pm 0.00 \mathrm{mgL}^{-1}$ at S3, S4 and S9 (T3), whereas the highest levels of total orthophosphate and total phosphate were found as $29.14 \pm 0.69 \mathrm{mgL}^{-1}$ at $\mathrm{S} 2$ in March and $0.57 \pm 0.01$ $\mathrm{mgL}^{-1}$ at $\mathrm{S} 2$ in April, respectively (Table 2). These stations have polluted with organic pollutions (sewage, animal waste and so on). According to Kivrak and Gürbüz (2010), the measurements of Tortum Stream waters were changed concentrations of nitrate $\left(\mathrm{NO}_{3}-\mathrm{N}\right) 0.1$ to $6.2 \mathrm{mgL}^{-1}$ concentration of ammonium $\left(\mathrm{NH}_{4}-\mathrm{N}\right) \quad 0.004$ to $0.48 \mathrm{mgL}^{-1}$, concentration of nitrite $\left(\mathrm{NO}_{2}-\mathrm{N}\right) 0.004$ to $0.76 \mathrm{mgL}^{-1}$ and concentrations of phosphate $\left(\mathrm{PO}_{4}-\mathrm{P}\right)$ of 0.07 and $0.256 \mathrm{mgL}^{-1}$. 


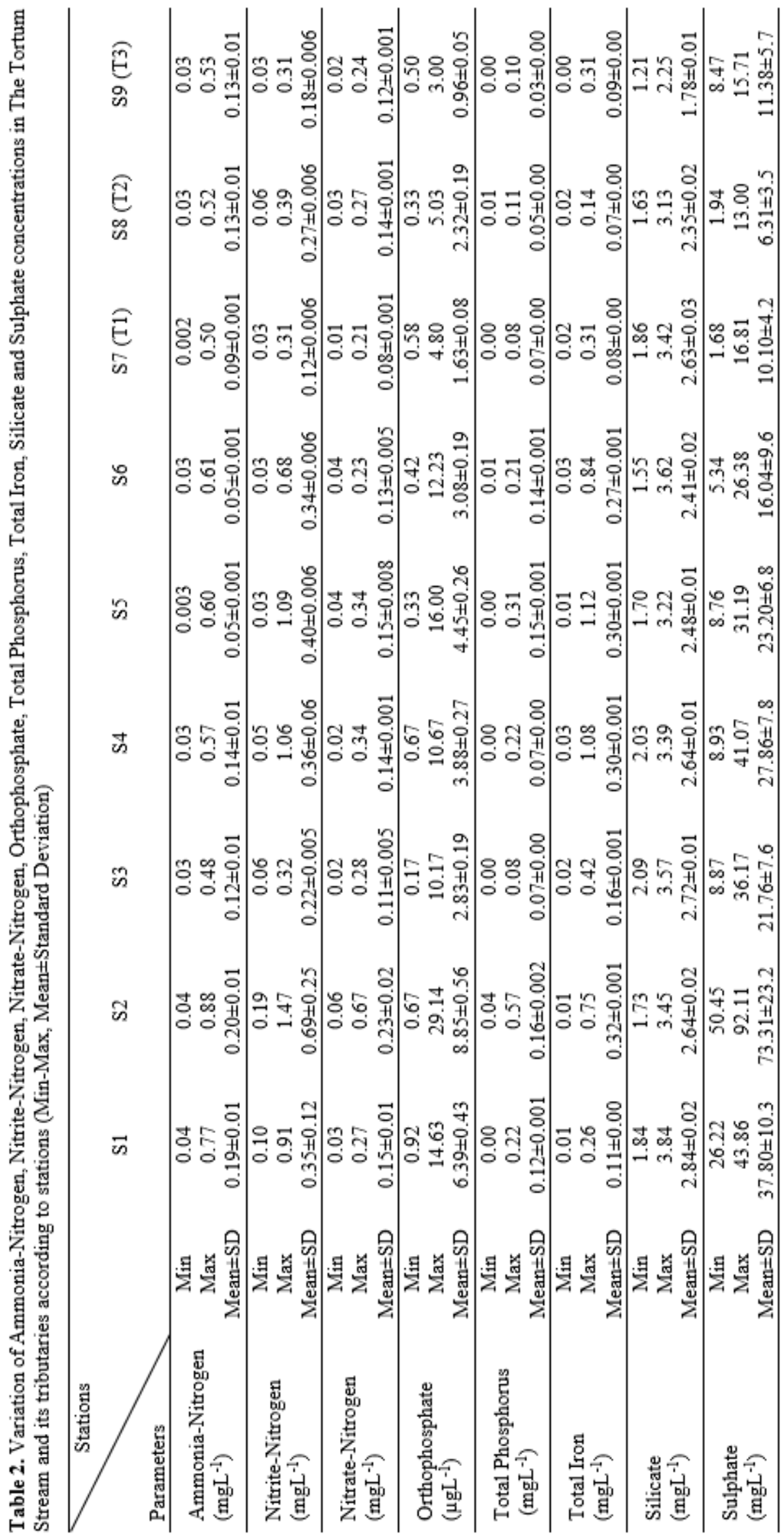


Heavy metals are widespread pollutants of great environmental concern as they are non-degradable, toxic and persistent with serious ecological ramifications on aquatic ecology (Aboud and Nandini 2009). Industrial and agricultural activities often results in introduction of nutrients and potentially hazardous levels of heavy metal into the river ecosystem (Kumar et al. 2013). But during this study, whereas the lowest Iron level in the Tortum Stream was found as $0.01 \pm 0.00 \mathrm{mgL}^{-1}$ at S1, S2, S5, S8 (T2) and S9 (T3) was found as $1.08 \pm 0.01 \mathrm{mgL}^{-1}$ at $\mathrm{S} 4$ where the discharge of agricultural effluent is the point source of pollution (Table 2). This study found a very low iron level due to factory is not in the work area. After the sediment study is reviewed in this area, we will be assessed at the right as a microelements.

Large rivers and lakes in the spring decrease the concentration of silicate with the proliferation of algae (Wetzel 2001). In river systems, mean silica concentration has been determined at $13 \mathrm{mgL}^{-1}$ (Horne and Goldman 1994). In this study, the minimum concentration of silica in the Tortum water was $1.21 \pm 0.00 \mathrm{mgL}^{-1}$ at $\mathrm{S} 9$ (T3) in October and the maximum concentration was $3.84 \pm 0.00 \mathrm{mgL}^{-1}$ at $\mathrm{S} 1$ in January (Table 2).

Allan (1995)'s claimed that the world's rivers, the waters of the river affected by human activities, the average concentration of sulfate was $5.11 \mathrm{mgL}^{-1}$, as in the unpolluted waters, average concentration of sulfate was $8.3 \mathrm{mgL}^{-1}$. In this study, while the lowest concentration of sulfate was found as $1.68 \pm 0.06 \mathrm{mgL}^{-1}$ at $\mathrm{S} 7$ (T1) in May, the highest concentration values were found as $92.11 \pm 12.49 \mathrm{mgL}^{-1}$ at $\mathrm{S} 2$ in December (Table 2).

Tortum Stream and its tributaries are classified contaminate waters according to the Turkey WQR. The present study has shown that the effect of HEP construction was lower than those caused by the anthropogenic pollutants.

Consequently, the below precautions should be taken for the continuation of the sustainable use of the ecosystem of the Tortum Stream and its tributaries:

1. Domestic waste coming from tributaries should be suck up sewer system and municipality must provide waste container for soil waste.

2. It must be raise the awareness of public about using organic fertilizer and other agricultural chemicals.

3. Stone quarries were established on the Tortum Stream is under taken control by the authorities.

4. Hydroelectric power plants should be built according to the rules and with minimum damage to the ecosystem and stripping must be stored in the appropriate places.

\section{Acknowledgements}

The authors wish to express their gratitude to the Ataturk University Scientific Research Project (project no. 2012/203). Suggestion and help provided by Assist. Prof. Dr. Özden FAKIOĞLU (Faculty of Fisheries, Atatürk University, Turkey) in analysis of data are thankfully acknowledged.

\section{References}

Aboud SJ, Nandini N. 2009. Heavy metal analysis and sediment quality value in urban lakes. Am J Env Sci. 5(6):678-687.

Allan JD. 1995. Stream ecology: structure and function of running waters. London: Cluwer Academic Publishers $388 \mathrm{p}$.

[Anonymous]. 2012. Yüzeysel su kalitesi yönetimi yönetmeliği. Resmi Gazete Sayı: 28483. [in Turkish].

APHA. 1995. Standard methods for the examination of water and wastewater. 19th ed. Washington: American Public Health Association.

Atalay İ, Tetik M, Yılmaz Ö. 1985. Kuzey Doğu Anadolu'nun ekosistemleri. Ormancilık Araş. Enst. Yay. Teknik Bült. Serisi, No:141. [in Turkish]

Brehm J, Meijering M. 1991. Fliessgewässerkunde. Heidelberg: Quelle \& Meyer Verlag 300 p.

Bricker OP, Jones BF. 1995. Main factors affecting the composition of natural waters. In: Salbu B, Steinnes $\mathrm{E}$, editors. Trace elements in natural waters. Boca Raton: CRC Press. p. 1-5.

Bunea F, Bucur DM, Dumitran GE, Ciocan GD. 2012. Water quality in hydroelectric sites. Ecological Water Quality - Water Treatment and Reuse. Edited by Dr. Voudouris; [cited 2015 Jan 20]. Available from http://www.intechopen.com/books/ecological-waterquality-water-treatment-and-reuse/water-quality-inhydroelectric-sites doi: 10.5772/32078

Calow P, Petts GE. 1994. The rivers handbook: hydrological and ecological principles. Oxford: Blackwell Science Ltd 523 p. doi: 10.1002/9781444313871

Gutierrez RL, Rubio-Arias H, Quintana R, Ortega JA, Gutierrez M. 2008. Heavy metals in water of the San Pedro River in Chihuahua, Mexico and its potential health risk. Int J Env Res Publ Health. 5(2):91-7827.

Horne AJ, Goldman CR. 1994. Limnology. $2^{\text {nd }}$ ed. New York: McGraw-Hill 57 p.

Jonnalagadda SB, Mhere G. 2001. Water quality of the Odzi River in the Eastern Highlands of Zimbabwe. Water Res. 35(10):2371-2376.

Kelley KD, Hudson T. 2007. Natural versus anthropogenic dispersion of metal to the environment in the Wulik River area western Brooks Range, northern Alaska. Geochemistry: Exploration, Environment, Analysis. 7(1):87-96.

Kesici T, Kocabaş Z. 2007. Biyoistatistik. Ankara: Ankara University. [in Turkish] 
Kıvrak E, Gürbüz H. 2010. Epipelic diatoms of Tortum Streams (Erzurum) and their relationship to some physicochemical features. Ekoloji. 19(74):102-109. doi: 10.5053/ekoloji.2010.7413 [in Turkish]

Kumar RN, Solanki R, Kumar NJI. 2013. Seasonal variation in heavy metal contamination in water and sediments of river Sabarmati and Kharicut canal at Ahmedabad, Gujarat. Environ Monit Assess. 185(1):359-368. doi: 10.1007/s10661-012-2558-4

Newbold JD. 1992. Cycles and spirals of nutrients. In: Calow P, Petts GE editors. The Rivers Handbook: Hidrological and Ecological Principles. Oxford: Blackwell Science Ltd. p. 379-408.

Peavy HS, Rowe DR, Tchobanoglous G. 1985. Environmental engineering. New York: McGraw-Hill Book Company $699 \mathrm{p}$.

Su Y, Yang R. 2008. Background concentrations of elements in surface soils and their changes as affected by agricultural use in the desert-oasis ecotone in the middle of Heihe River Basin, Northern West China. J Geophysical Explor. 98(3):57-64. doi: 10.1016/j.gexplo.2007.12.001

Vega M, Pardo R, Barrado E, Deban L. 1998. Assessment of seasonal and polluting effects on the quality of river water by exploratory data analysis. Water Res. 32(12):3581-3592. doi: 10.1016/S0043-1354(98)00138-9

Walling DE, Webb BW. 1986. Solutes in river systems. In: ST Trudgill editor, Solute processes. Chichester: John Wiley \& Sons. p. 251-327.

Wetzel RG, Likens GE. 2001. Limnological analyses. $2^{\text {nd }}$ ed. New York: Springer Verlag 391 p.

Wetzel RG. 2001. Limnology: Lake and river ecosystems. $3^{\text {rd }}$ ed. San Diego: Academic Press 1006 p.

WHO 2004. Guidelines for drinking water quality, $3^{\text {rd }}$ ed. World Health Organization. p 516. 